\title{
Results of reoperation for failed ulnar nerve surgery at the elbow: a systematic review and meta-analysis
}

\author{
Tinatin Natroshvili, MD, ${ }^{1}$ Erik T. Walbeehm, MD, PhD, ${ }^{1}$ Nens van Alfen, MD, $\mathrm{PhD},{ }^{2}$ and \\ Ronald H. M. A. Bartels, MD, PhD
}

\begin{abstract}
Departments of ${ }^{1}$ Plastic and Reconstructive Surgery; ${ }^{2}$ Department of Neurology, Donders Institute for Brain, Cognition and Behaviour; and ${ }^{3}$ Department of Neurosurgery, Radboud University Medical Center, Nijmegen, The Netherlands
\end{abstract}

\begin{abstract}
OBJECTIVE The clinical results of reoperation for recurrent or persistent ulnar nerve compression at the elbow have not been clearly determined. The aim of this review was to determine overall improvement, residual pain, and sensory and motor deficits following reoperation regardless of the type of primary surgery performed for this condition.

METHODS In accordance with Preferred Reporting Items for Systematic Reviews and Meta-Analyses (PRISMA) recommendations, a systematic review and meta-analysis of studies was performed. An independent librarian performed a literature search using Ovid MEDLINE, Embase, CINAHL, and the Cochrane Central Register of Controlled Trials (CENTRAL). The Newcastle-Ottawa Scale and the quality appraisal tool described by Moga et al. were used to assess the quality of included case series.
\end{abstract}

RESULTS Of the 278 retrieved studies, 16 were eligible for analysis and included a total of 290 patients with failed surgery for ulnar nerve entrapment at the elbow. Relief of symptoms after reoperation was reported in $85 \%$ of patients. A decrease in pain was noted in $85 \%$ of the patients (95\% Cl $75 \%-93 \%)$. Only $2.4 \%$ of patients with preoperative pain experienced worse pain after reoperation. Motor and sensory function improvement was noted in $77 \%(95 \% \mathrm{Cl} 63 \%-88 \%)$ and $77 \%(95 \% \mathrm{Cl} 61 \%-90 \%)$ of cases, respectively. Complete recovery from signs and symptoms at the final follow-up was noted in $23 \%$ of elbows $(95 \% \mathrm{Cl} 16 \%-31 \%)$.

CONCLUSIONS Although the level of evidence of the included studies was low, the majority of patients had relief from their complaints after reoperation for recurrent or persistent ulnar nerve compression at the elbow following a previous surgery. The success rate of surgical treatment for a failed surgery was quite remarkable since almost a quarter of the patients completely recovered. Therefore, the authors recommend reoperation as a serious option for patients with this condition.

https://thejns.org/doi/abs/10.3171/2017.8.JNS17927

KEYWORDS compression; persistent; recurrent; reoperation; ulnar nerve; peripheral nerve

$\mathrm{T}$ HE average annual crude incidence rate of ulnar nerve entrapment at the elbow is 24.7 cases per 100,000 person-years. ${ }^{16}$ It is the second most common nerve compression syndrome of the upper extremity after carpal tunnel syndrome. Surgery is indicated if conservative treatment fails or in cases of more severe sensory and/or motor dysfunction. Despite a variety of surgical options for ulnar nerve entrapment at the elbow, the failure of surgical treatment, expressed as the persistence, recurrence, or even worsening of symptoms, occurs in approximately $10 \%-25 \%$ of cases. ${ }^{1,4,20}$
Recurrent or persistent ulnar nerve compression at the elbow is a challenge from a surgical point of view. ${ }^{17}$ Results of reoperation are less predictable and less favorable than those for the primary surgery regardless of the type of primary surgery performed.,21 Optimal management of failed surgical treatment remains controversial, and the choice of the type of surgery to perform mostly depends on the experience of the surgeon. Because results of the reoperation in patients who suffer from persistent or recurrent ulnar compression at the elbow have never been systematically analyzed, we performed this systematic review. 


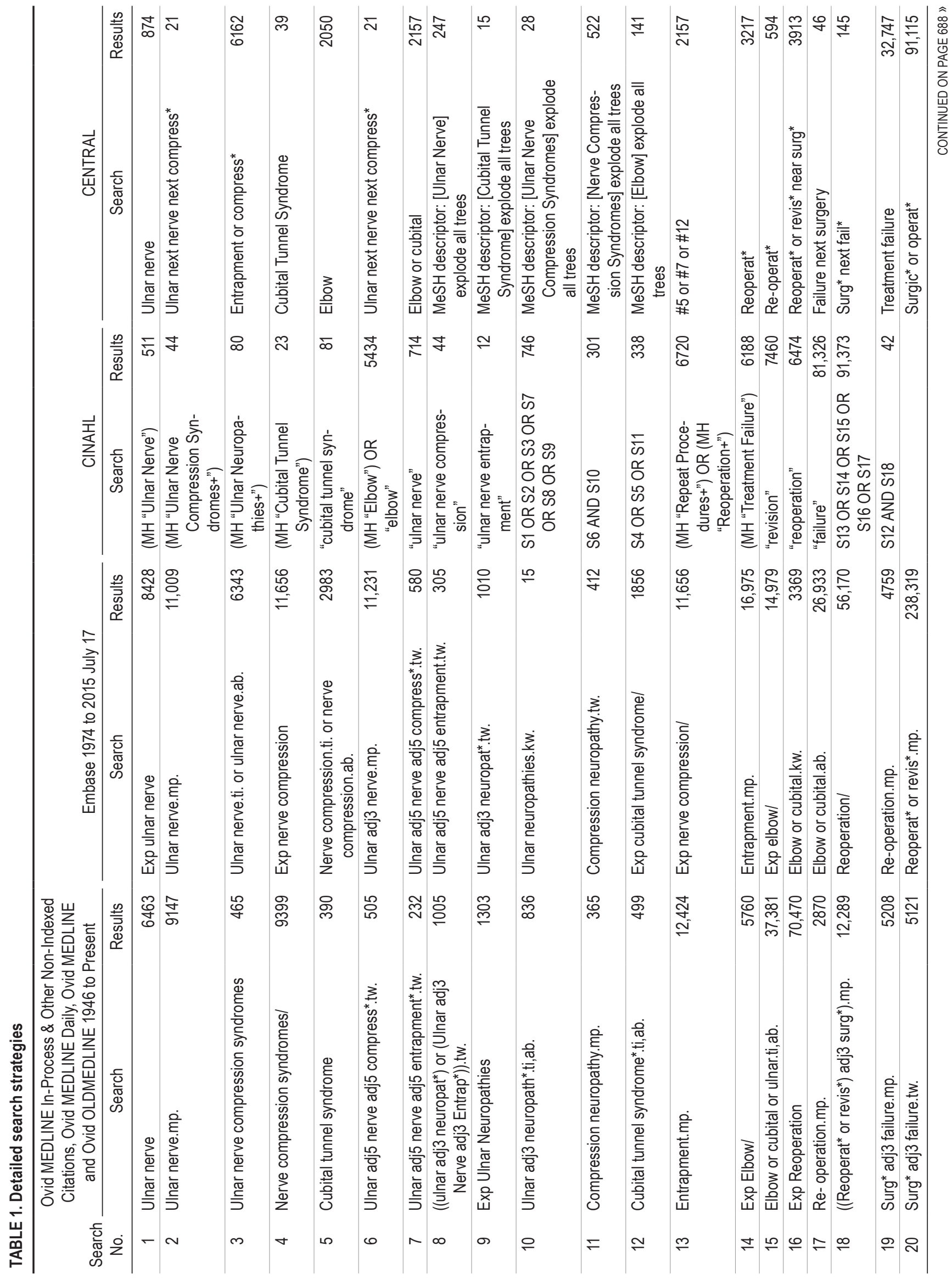




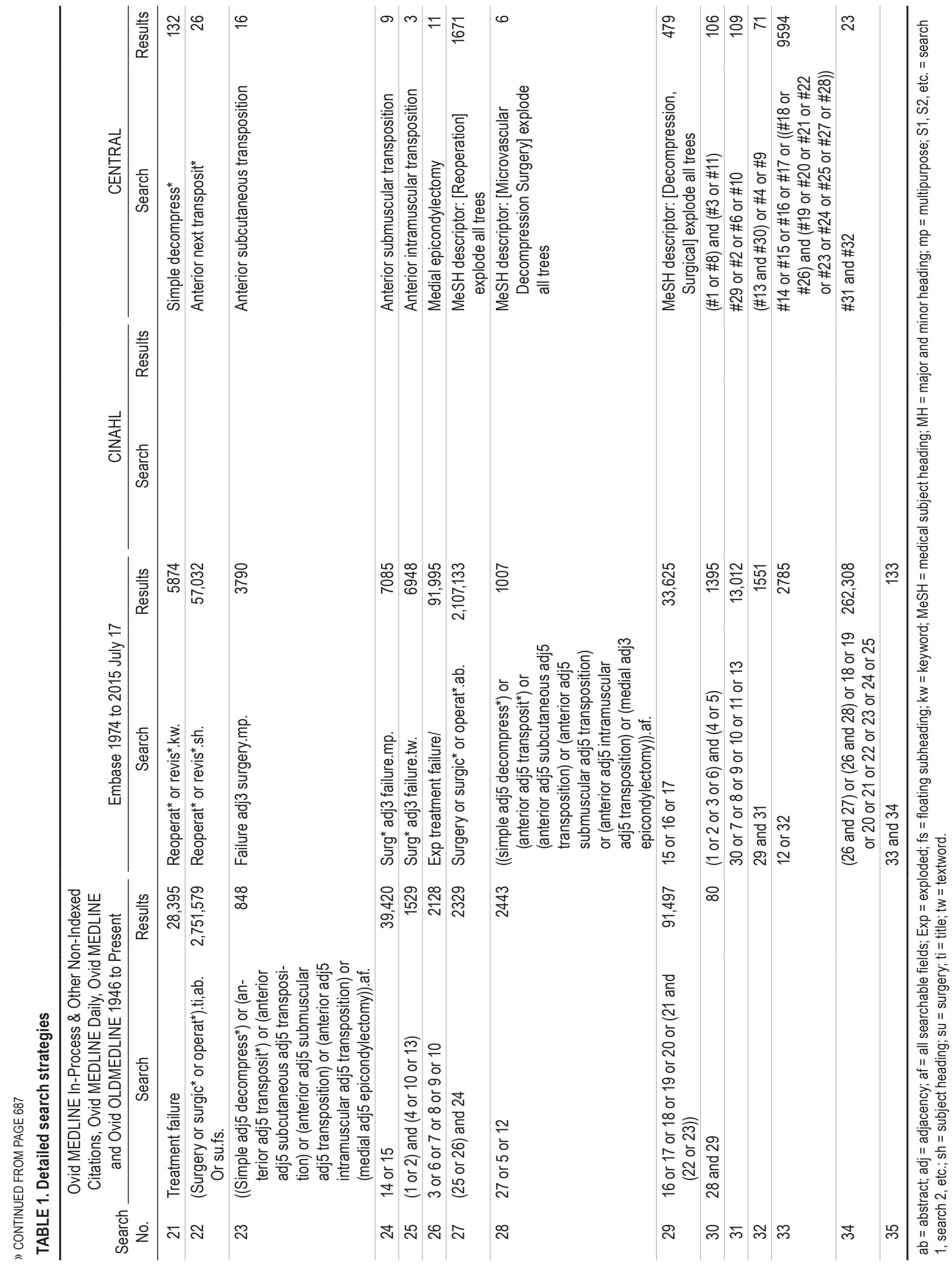




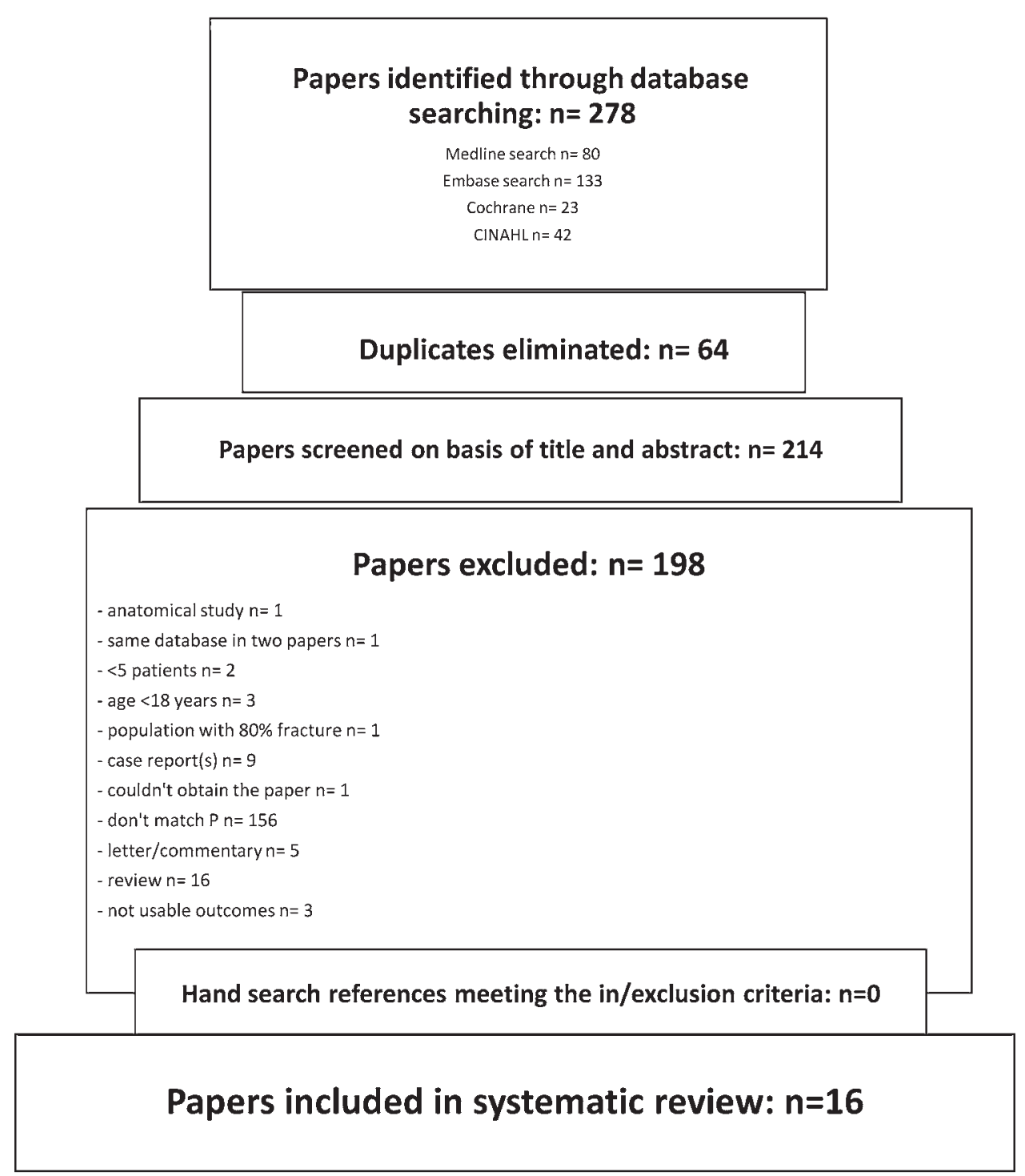

FIG. 1. Study identification process. $N$ = number of studies; $P=$ surgery for recurrent or persistent symptoms of ulnar nerve entrapment at the elbow after previous surgical treatment for ulnar nerve entrapment at the elbow.

\section{Methods}

This review was performed in accordance with the Preferred Reporting Items for Systematic Reviews and MetaAnalyses (PRISMA) recommendations..$^{15}$

\section{Search Methods for the Identification of Studies}

An experienced, independent librarian performed a search of the literature in MEDLINE, Embase, CINAHL, and the Cochrane Central Register of Controlled Trials (CENTRAL). The search was last updated on July 2015. Geographic or language restrictions were not formulated. The detailed search strategies are described in Table 1. Two authors reviewed the abstracts and titles, and once the studies were selected they also reviewed the full-text articles. In cases of disagreement the reviewers discussed the reason, and if the discussion was not closed a third reviewer intervened. Reference lists were screened for addi- tional studies. Authors were not contacted for unpublished results.

\section{Eligibility Criteria}

Studies were considered eligible for inclusion if they met the following criteria. The study group included at least five patients who were 18 years or older and had undergone surgery for recurrent or persistent symptoms of ulnar nerve entrapment at the elbow following previous surgical treatment of the condition, regardless of the type of primary and repeat surgery performed. The study included well-described outcomes measurement with a minimal description of the postoperative outcome for ulnar nerve entrapment symptoms as "improved" or "not improved." If we found the same data in more than one article, the article with the most complete data set was included. 


\begin{tabular}{|c|c|c|c|c|c|c|c|c|}
\hline Authors \& Year & Title & Journal & Country & $\begin{array}{l}\text { Type of } \\
\text { Study }\end{array}$ & $\begin{array}{l}\text { Level of } \\
\text { Evidence }\end{array}$ & $\begin{array}{l}\text { Funding } \\
\text { or } \\
\text { Conflict } \\
\text { of } \\
\text { Interest }\end{array}$ & $\begin{array}{l}\text { Methodological } \\
\text { Quality } \\
\text { Assessment }\end{array}$ & $\begin{array}{l}\text { STROBE } \\
\text { Score }\end{array}$ \\
\hline $\begin{array}{l}\text { Aleem et al., } \\
2014\end{array}$ & $\begin{array}{l}\text { Outcomes of revision surgery for cubital } \\
\text { tunnel syndrome }\end{array}$ & $\begin{array}{l}\text { J Hand Surg } \\
\qquad A m\end{array}$ & US & $\begin{array}{l}\text { Case } \\
\text { control }\end{array}$ & III & No & Mod & High \\
\hline $\begin{array}{l}\text { Antoniadis \& } \\
\text { Richter, } 1997 \\
\end{array}$ & $\begin{array}{l}\text { Pain after surgery for ulnar neuropathy at } \\
\text { the elbow: a continuing challenge }\end{array}$ & Neurosurgery & Germany & $\begin{array}{l}\text { Case } \\
\text { series }\end{array}$ & IV & NM & Low & Low \\
\hline $\begin{array}{l}\text { Bartels \& } \\
\text { Grotenhuis, } \\
2004\end{array}$ & $\begin{array}{l}\text { Anterior submuscular transposition of the } \\
\text { ulnar nerve. For post-operative focal } \\
\text { neuropathy at the elbow }\end{array}$ & $\begin{array}{l}\text { J Bone Joint } \\
\text { Surg Br }\end{array}$ & $\begin{array}{l}\text { Nether- } \\
\text { lands }\end{array}$ & $\begin{array}{l}\text { Case } \\
\text { series }\end{array}$ & IV & No & High & High \\
\hline $\begin{array}{l}\text { Broudy et al., } \\
1978\end{array}$ & $\begin{array}{l}\text { Technical problems with ulnar nerve } \\
\text { transposition at the elbow: findings and } \\
\text { results of reoperation }\end{array}$ & $\begin{array}{l}\text { J Hand Surg } \\
\qquad A m\end{array}$ & US & $\begin{array}{l}\text { Case } \\
\text { series }\end{array}$ & IV & NM & Mod & Mod \\
\hline $\begin{array}{l}\text { Caputo \& Wat- } \\
\text { son, } 2000\end{array}$ & $\begin{array}{l}\text { Subcutaneous anterior transposition of the } \\
\text { ulnar nerve for failed decompression of } \\
\text { cubital tunnel syndrome }\end{array}$ & $\begin{array}{l}\text { J Hand Surg } \\
\qquad A m\end{array}$ & US & $\begin{array}{l}\text { Case } \\
\text { series }\end{array}$ & IV & No & Mod & Mod \\
\hline $\begin{array}{l}\text { Dagregorio \& } \\
\text { Saint-Cast, } \\
2004\end{array}$ & $\begin{array}{l}\text { Simple neurolysis for failed anterior sub- } \\
\text { muscular transposition of the ulnar nerve } \\
\text { at the elbow }\end{array}$ & Int Orthop & France & $\begin{array}{l}\text { Case } \\
\text { series }\end{array}$ & IV & NM & Mod & Mod \\
\hline $\begin{array}{l}\text { Filippi et al., } \\
2001\end{array}$ & $\begin{array}{l}\text { Recurrent cubital tunnel syndrome. Etiology } \\
\text { and treatment }\end{array}$ & $\begin{array}{l}\text { Minim Invasive } \\
\text { Neurosurg }\end{array}$ & Germany & $\begin{array}{l}\text { Case } \\
\text { series }\end{array}$ & IV & NM & Mod & Mod \\
\hline $\begin{array}{l}\text { Gabel \& Ama- } \\
\text { dio, } 1990\end{array}$ & $\begin{array}{l}\text { Reoperation for failed decompression of } \\
\text { the ulnar nerve in the region of the elbow }\end{array}$ & $\begin{array}{l}\text { J Bone Joint } \\
\text { Surg Am }\end{array}$ & US & $\begin{array}{l}\text { Case } \\
\text { series }\end{array}$ & IV & Yes & Mod & Mod \\
\hline $\begin{array}{l}\text { Goldfarb et al., } \\
2009\end{array}$ & $\begin{array}{l}\text { Incidence of re-operation and subjective } \\
\text { outcome following in situ decompression } \\
\text { of the ulnar nerve at the cubital tunnel }\end{array}$ & $\begin{array}{l}\text { J Hand Surg } \\
\text { Eur Vol }\end{array}$ & US & $\begin{array}{l}\text { Case } \\
\text { series }\end{array}$ & IV & Yes & Mod & High \\
\hline Holmberg, 1991 & Reoperation in high ulnar neuropathy & $\begin{array}{l}\text { Scand J Plast } \\
\text { Reconstr } \\
\text { Surg Hand } \\
\text { Surg }\end{array}$ & Sweden & $\begin{array}{l}\text { Case } \\
\text { series }\end{array}$ & IV & NM & Mod & Low \\
\hline $\begin{array}{l}\text { Kokkalis et al., } \\
2010\end{array}$ & $\begin{array}{l}\text { Vein wrapping at cubital tunnel for ulnar } \\
\text { nerve problems }\end{array}$ & $\begin{array}{l}\text { J Shoulder } \\
\text { Elbow Surg }\end{array}$ & US & $\begin{array}{l}\text { Case } \\
\text { series }\end{array}$ & IV & No & Mod & Mod \\
\hline $\begin{array}{l}\text { Papatheodorou } \\
\text { et al., } 2015\end{array}$ & $\begin{array}{l}\text { Preliminary results of recurrent cubital tun- } \\
\text { nel syndrome treated with neurolysis and } \\
\text { porcine extracellular matrix nerve wrap }\end{array}$ & $\begin{array}{l}\text { J Hand Surg } \\
\qquad \mathrm{Am}\end{array}$ & US & $\begin{array}{l}\text { Case } \\
\text { series }\end{array}$ & IV & Yes & Mod & Mod \\
\hline $\begin{array}{l}\text { Rogers et al., } \\
1991\end{array}$ & $\begin{array}{l}\text { The failed ulnar nerve transposition. Etiol- } \\
\text { ogy and treatment }\end{array}$ & $\begin{array}{l}\text { Clin Orthop } \\
\text { Relat Res }\end{array}$ & US & $\begin{array}{l}\text { Case } \\
\text { series }\end{array}$ & IV & NM & Mod & Mod \\
\hline $\begin{array}{l}\text { Sarris et al., } \\
\quad 2002\end{array}$ & $\begin{array}{l}\text { Medial brachial and antebrachial cutane- } \\
\text { ous nerve injuries: effect on outcome in } \\
\text { revision cubital tunnel surgery }\end{array}$ & $\begin{array}{l}\text { J Reconstr } \\
\text { Microsurg }\end{array}$ & US & $\begin{array}{l}\text { Case } \\
\text { series }\end{array}$ & IV & NM & Mod & Mod \\
\hline $\begin{array}{l}\text { Soltani et al., } \\
2014\end{array}$ & $\begin{array}{l}\text { Revision decompression and collagen } \\
\text { nerve wrap for recurrent and persistent } \\
\text { compression neuropathies of the upper } \\
\text { extremity }\end{array}$ & Ann Plast Surg & US & $\begin{array}{l}\text { Case } \\
\text { series }\end{array}$ & IV & NM & Mod & Mod \\
\hline $\begin{array}{l}\text { Vogel et al., } \\
2004\end{array}$ & $\begin{array}{l}\text { Revision anterior submuscular transposition } \\
\text { of the ulnar nerve for failed subcutane- } \\
\text { ous transposition }\end{array}$ & Br J Plast Surg & US & $\begin{array}{l}\text { Case } \\
\text { series }\end{array}$ & IV & NM & Mod & Mod \\
\hline
\end{tabular}

Mod = moderate $;$ NM = not mentioned .

All studies had a retrospective design. 
TABLE 3. Summary of data in studies included in the systematic review

\begin{tabular}{|c|c|c|c|c|c|c|c|}
\hline Authors \& Year & $\begin{array}{c}\text { Database Yrs/Study } \\
\text { Period }\end{array}$ & $\begin{array}{l}\text { No. of } \\
\text { Patients in } \\
\text { Revision } \\
\text { Group/ No. } \\
\text { of Elbows }\end{array}$ & $\begin{array}{l}\text { Males (no. [\%])/ } \\
\text { Females (no. } \\
[\%])\end{array}$ & $\begin{array}{l}\text { Mean Age } \\
\text { in Yrs } \\
\text { (range) }\end{array}$ & $\begin{array}{l}\text { Interval to } \\
\text { Reoperation } \\
\text { in Mos }\end{array}$ & $\begin{array}{l}\text { Mean FU in } \\
\text { Yrs (range) }\end{array}$ & Complications \\
\hline Aleem et al., 2014 & January 2006-July 2011 & $28 / 28$ & $11(39) / 17(61)$ & $55(32-72)$ & NA & $3.4(2.0-6.2)$ & NA \\
\hline $\begin{array}{l}\text { Antoniadis \& Richter, } \\
\quad 1997\end{array}$ & $\begin{array}{l}\text { October 1989-March } \\
1995\end{array}$ & $25 / 25$ & NA & $45(22-87)$ & NA & $1.4(0.2-4.6)$ & $\begin{array}{l}\text { No postop infections, } 1 \\
\text { evacuation of subcuta- } \\
\text { neous hematoma w/o } \\
\text { nerve compression }\end{array}$ \\
\hline $\begin{array}{l}\text { Bartels \& Grotenhuis, } \\
2004\end{array}$ & $\begin{array}{l}\text { November 1997-No- } \\
\text { vember } 2002\end{array}$ & $40 / 41$ & $15(37.5) / 25(62.5)$ & $50(25-75)$ & 17 & $1.0(0.2-4.2)$ & $\begin{array}{l}8 \text { patients (21\%); pain } \\
\text { in } 4 \text { th \& } 5 \text { th fingers, } \\
\text { numbness, cold intol- } \\
\text { erance, pain at elbow }\end{array}$ \\
\hline Broudy et al., 1978 & NA & $10 / 10$ & $3(30) / 7(70)$ & $42(18-71)$ & 13 & $1.2(0.5-2.5)$ & NA \\
\hline $\begin{array}{l}\text { Caputo \& Watson, } \\
2000\end{array}$ & $1980-1993$ & $20 / 20$ & $13(65) / 7(35)$ & $47(24-70)$ & 13 & $2.7(2.0-7.0)$ & NA \\
\hline $\begin{array}{l}\text { Dagregorio \& Saint- } \\
\text { Cast, } 2004\end{array}$ & $1996-2000$ & $9 / 9$ & $7(78) / 2(22)$ & $47(32-66)$ & NA & $2.0(\mathrm{NA})$ & $\begin{array}{l}1 \text { patient; lat epicondyli- } \\
\text { tis, pain on palpation } \\
\text { of transposed ulnar } \\
\text { nerve or when flexing } \\
\text { elbow }\end{array}$ \\
\hline Filippi et al., 2001 & NA & $22 / 22$ & $9(41) / 13(59)$ & $42(27-76)$ & $4-108$ & $0.6(0.2-1.7)$ & $\begin{array}{l}\text { No postop infections, } \\
\text { other complications } \\
\text { not mentioned }\end{array}$ \\
\hline Gabel \& Amadio, 1990 & 1979-1985 & $30 / 30$ & $18(60) / 12(40)$ & $40(18-75)$ & 46 & $3.6(2.0-9.4)$ & No postop infections \\
\hline Goldfarb et al., 2009 & $1996-2006$ & $5 / 5$ & NA & $52(20-80)$ & NA & $4.1(1.1-7.8)$ & NA \\
\hline Holmberg, 1991 & NA & $14 / 16$ & NA & $52(15-74)$ & 18 & $1.7(0.3-2.5)$ & NA \\
\hline Kokkalis et al., 2010 & 1995-2007 & $17 / 17$ & $8(47) / 9(53)$ & $51(30-67)$ & NA & $3.7(2.0-7.3)$ & $\begin{array}{l}\text { No complications of } \\
\text { upper extremity, } 1 \\
\text { patient w/ transient } \\
\text { leg swelling caused by } \\
\text { harvesting saphenous } \\
\text { vein graft from leg }\end{array}$ \\
\hline $\begin{array}{l}\text { Papatheodorou et al., } \\
2015\end{array}$ & May 2009-June 2012 & $12 / 12$ & $8(67) / 4(33)$ & $45(30-58)$ & 18 & $3.4(2.0-5.1)$ & No complications \\
\hline Rogers et al., 1991 & NA & $14 / 14$ & $8(57) / 6(43)$ & $36(16-59)$ & 9 & $1.6(0.8-4.0)$ & NA \\
\hline Sarris et al., 2002 & 1992-1999 & $20 / 20$ & NA & NA & 18 & $2.2(1.1-7.0)$ & NA \\
\hline Soltani et al., 2014 & $\begin{array}{l}\text { September 2007-Janu- } \\
\quad \text { ary } 2013\end{array}$ & $6 / 6$ & NA & $57(47-66)$ & 44 & $1.1(\mathrm{NA})$ & NA \\
\hline Vogel et al., 2004 & 1989-2000 & $18 / 18$ & $9(50) / 9(50)$ & 44 (NA) & 54 & $2.8(0.5-7.0)$ & NA \\
\hline
\end{tabular}

$\mathrm{NA}=$ information not available.

Excluded studies involved animals or other nonhuman experiments or were single case reports, letters, or reviews. Studies in which the initial surgery was not primarily for ulnar nerve entrapment were also excluded, as were studies including more than $30 \%$ of patients in the group with bone fracture of the elbow on the side of nerve entrapment. Studies were also excluded if the ulnar nerve surgery was not the main procedure performed during the same operative session. If more studies were published based on the same data, the article with the most extensive data was included.

\section{Quality Assessment}

The quality of included case-control studies was assessed using the Newcastle-Ottawa Scale (NOS). This scale looks at three elements: selection of the study groups, comparability of the groups, and evaluation of the exposure. Quality assessment is performed using a star system with 9 stars as the maximum possible star score for casecontrol studies. ${ }^{23}$ Studies with a score of 7-9 stars were defined as high quality, 4-6 stars as moderate quality, and $0-3$ as low quality.

The quality of included case series was assessed with 
TABLE 4. Primary operation and reoperation types per study

\begin{tabular}{|c|c|c|}
\hline Authors \& Year & Failed Surgical Procedure (\%) & Type of Revision Surgery (\%) \\
\hline Aleem et al., 2014 & ISD 26 (92.9\%), SCT 2 (7.1\%) & ISD 1 (3.6\%), SCT 5 (17.9\%), IMT 1 (3.6\%), SMT 21 (75.0\%) \\
\hline Antoniadis \& Richter, 1997 & ISD 10 (40.0\%), AT 15 (60.0\%) & $\begin{array}{l}\text { AT } 7(28.0 \%) \text {, AT \& EN } 3(12.0 \%) \text {, nerve replaced in its } \\
\text { original bed } 5(20.0 \%) \text {, EN } 5(20.0 \%) \text {, EpN } 1(4.0 \%) \text {, IN } \\
\quad 4(16.0 \%)\end{array}$ \\
\hline Bartels \& Grotenhuis, 2004 & $\begin{array}{l}\text { ISD } 20 \text { (48.8\%), SCT } 12 \text { (29.3\%), ISD \& SCT } 3(7.3 \%), \text { ME } \\
4 \text { (9.8\%), EN after SCT } 2(4.9 \%)\end{array}$ & SMT \& EN $41(100 \%)$ \\
\hline Broudy et al., 1978 & $\begin{array}{l}\text { SCT } 5(50 \%) \text {, SMT } 1(10 \%) \text {, nerve located in channel cut } \\
\quad \text { into muscle } 4(40 \%)\end{array}$ & N 2 (20\%), N \& EpN $8(80 \%)$ \\
\hline Caputo \& Watson, 2000 & SMT 4 (20\%), SCT 12 (60\%), N 4 (20\%) & SCT $20(100 \%)$ \\
\hline $\begin{array}{l}\text { Dagregorio \& Saint-Cast, } \\
\quad 2004\end{array}$ & Subfascial-submuscular ant transposition $9(100 \%)$ & EN $9(100 \%)$ \\
\hline Filippi et al., 2001 & AT 10 (45.5\%), ISD 5 (22.7\%), NA 7 (31.8\%) & $\begin{array}{l}\text { EN } 10(45.5 \%) \text {, repositioning of nerve } 7 \text { (31.8\%), ISD } 4 \\
\quad(18.2 \%) \text {, AT } 1(4.5 \%)\end{array}$ \\
\hline Gabel \& Amadio, 1990 & INA & SMT 24 (80\%), SCT 5 (17\%), IMT 1 (3\%) \\
\hline Goldfarb et al., 2009 & ISD $5(100 \%)$ & SMT $5(100 \%)$ \\
\hline Holmberg, 1991 & N $10(62.5 \%)$, SCT $6(37.5 \%)$ & SMT 12 (75\%), SCT 4 (25\%) \\
\hline Kokkalis et al., 2010 & INA & Vein wrapping 17 (100\%) \& IN NA \\
\hline Papatheodorou et al., 2015 & SMT 6 (50\%), SCT 2 (16.7\%), ME 4 (33.3\%) & N \& porcine extracellular matrix nerve wrap $12(100 \%)$ \\
\hline Rogers et al., 1991 & INA & EN \& SMT 14 (100\%) \\
\hline Sarris et al., 2002 & $\begin{array}{l}\text { SCT } 8(40 \%), \text { SMT } 4(20 \%), \text { ISD } 2(10 \%), \text { ME } 2(10 \%), \text { NA } \\
\quad 4(20 \%)\end{array}$ & $\begin{array}{l}\text { N w/ SCT or SMT; no description of distribution available } \\
20(100 \%)\end{array}$ \\
\hline Soltani et al., 2014 & INA & SMT 3 (50\%), EN 3 (50\%) \\
\hline Vogel et al., 2004 & SCT 14 (77.8\%), ME 2 (11.1\%), SMT 1 (5.6\%), SCT 1 (5.6\%) & EN + SMT $18(100 \%)$, in combination w/ IN NA \\
\hline
\end{tabular}

ant = anterior; AT = anterior transposition; EN = external neurolysis; EpN = epineurectomy; IMT = intramuscular transposition; IN = internal neurolysis; INA = no information about precise failed procedure before revision; $\mathrm{ISD}=$ in situ decompression; $\mathrm{ME}=$ medial epicondylectomy; $\mathrm{N}=$ neurolysis; $\mathrm{NA}=$ information not available; $\mathrm{SCT}=$ subcutaneous transposition; SMT = submuscular transposition.

a tool developed by Moga et al. in 2002 using a modified Delphi technique. The tool consists of 18 items, and scores range from 0 to 18 . Studies receiving a score of 13 or more of the possible 18 points were rated as high quality, studies with 7-12 points as moderate quality, and studies with $0-6$ points as low quality. ${ }^{14}$

To ensure clear presentation of reporting, included studies were scored using the Strengthening the Reporting of Observational Studies in Epidemiology (STROBE) Statement. 22

Two reviewers conducted the quality appraisal. Any disagreements during the process were discussed and resolved by adjudication by a third reviewer.

\section{Data Extraction}

Data were independently extracted by two reviewers. The following data were extracted from the studies: total number of patients, demographics, type of previous surgery, type of revision procedure, type of symptoms (for example, recurrent or persistent symptoms), subjective and objective outcome measurements for pain, sensory or motor function improvement after reoperation. In cases of different interpretations, the results were discussed again by the two reviewers and resolved by adjudication by a third reviewer.
Motor improvement was defined as improvement based on one of the following: McGowan scale, Medical Research Council grade, weakness, strength, and grip strength. Preoperative and postoperative data on motor function were compared, and the percentage of improvement in comparison with the entire group of patients with preoperative motor dysfunction was calculated. Information about sensation in the hand, numbness, and 2-point discrimination was used to calculate the number of patients with sensory improvement. As for sensory function, pre- and postoperative data on sensation were compared and the percentage of improvement in comparison with the entire group of patients with preoperative sensory dysfunction was calculated.

Improvement in pain was calculated as the proportion of patients with measured improvement in pain from the number of patients with preoperative pain. Data about pain worsening after reoperation was calculated as the proportion of patients with worsening pain from the number of patients with preoperative hand pain.

Symptom recurrence was defined as the return of symptoms of ulnar nerve compression after a symptom-free period following operation. Persistence of symptoms of ulnar nerve compression at the elbow was defined as symptoms that did not change and remained the same after operation for ulnar nerve compression at the elbow. 
A

Aleem et al., 2014

Antoniadis and Richter, 1997

Bartels and Grotenhuis, 2004

Broudy et al., 1978

Caputo and Watson, 2000

Dagregorio and Saint-Cast, 2004

Filippi et al., 2001

Gabel and Amadio, 1990

Goldfarb et al., 2009

Holmberg, 1991

Kokkalis et al., 2010

Papatheodorou et al., 2015

Rogers et al., 1991

Sarris et al., 2002

Soltani et al., 2014

Vogel et al., 2004
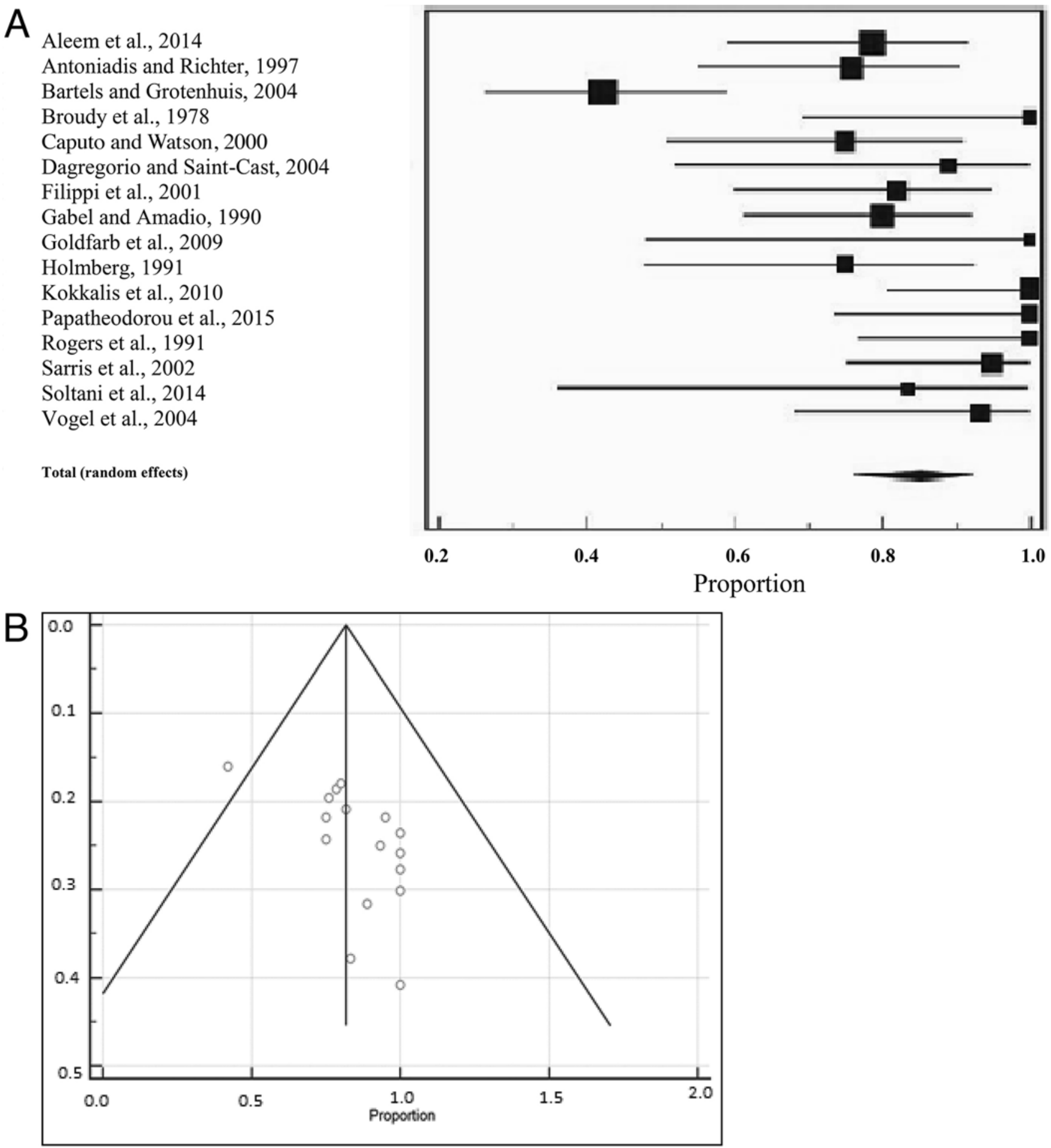

C Test for heterogeneity

\begin{tabular}{|l|l|}
\hline $\mathrm{Q}$ & 57.0495 \\
\hline $\mathrm{DF}$ & 15 \\
\hline Significance level & $\mathrm{P}<0.0001$ \\
\hline $\mathrm{I}^{2}$ (inconsistency) & $73.71 \%$ \\
\hline $95 \%$ CI for $\mathrm{I}^{2}$ & 56.89 to 83.96 \\
\hline
\end{tabular}

FIG. 2. Forest plot (A) and funnel plot (B) showing pooled results of overall symptomatic improvement in proportions of improved patients with $95 \%$ Cls per included study and table (C) indicating heterogeneity data. 
A

Antoniadis and Richter, 1997

Bartels and Grotenhuis, 2004

Broudy et al., 1978

Caputo and Watson, 2000

Filippi et al., 2001

Gabel and Amadio, 1990

Goldfarb et al., 2009

Holmberg, 1991

Kokkalis et al., 2010

Papatheodorou et al., 2015

Rogers et al., 1991

Soltani et al., 2014

Vogel et al., 2004

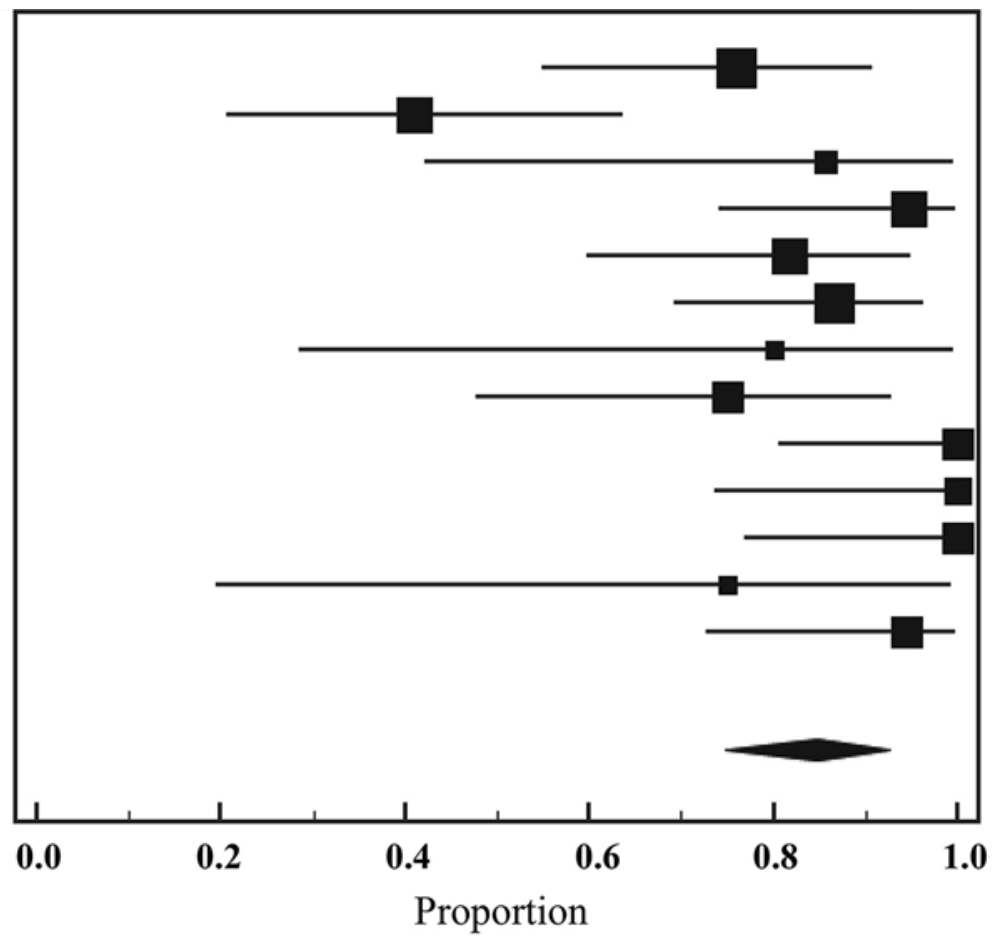

B

Total (random effects)

Proportion

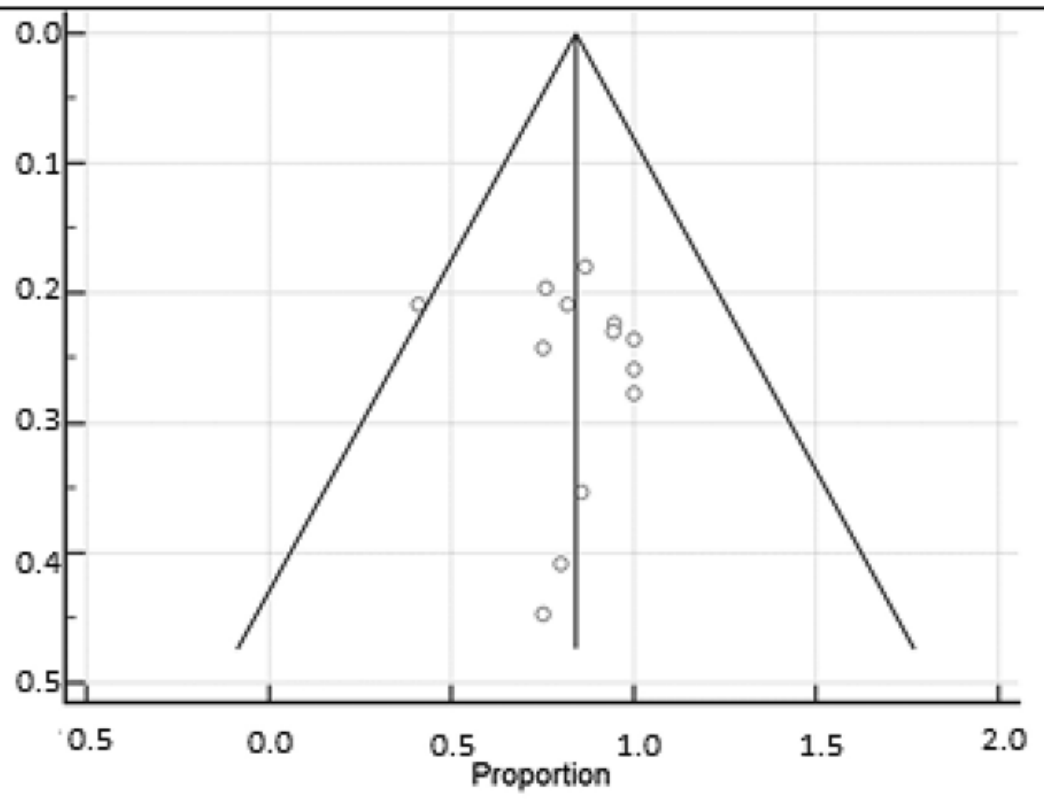

C

\begin{tabular}{|l|l|}
\hline \multicolumn{2}{|l|}{ Test for heterogeneity } \\
\hline $\mathrm{Q}$ & 40.6153 \\
\hline $\mathrm{DF}$ & 12 \\
\hline Significance level & $\mathrm{P}=0.0001$ \\
\hline $\mathrm{I}^{2}$ (inconsistency) & $70.45 \%$ \\
\hline $95 \%$ CI for $\mathrm{I}^{2}$ & 47.93 to 83.24 \\
\hline
\end{tabular}

FIG. 3. Forest plot (A) and funnel plot (B) showing pooled results of pain decrease in proportions of improved patients with $95 \%$ Cls per included study and table $(\mathbf{C})$ indicating heterogeneity data. 
TABLE 5. Preoperatively present pain worsening after reoperation

\begin{tabular}{|c|c|c|c|}
\hline Authors \& Year & $\begin{array}{l}\text { No. of Patients } \\
\text { w/ Pain } \\
\text { Worsening } \\
\text { After } \\
\text { Reoperation }\end{array}$ & $\begin{array}{l}\text { Total No. of } \\
\text { Patients w/ } \\
\text { (Hand) Pain } \\
\text { Preoperatively }\end{array}$ & $\begin{array}{c}\text { Total } \\
\text { No. of } \\
\text { Patients }\end{array}$ \\
\hline Aleem et al., 2014 & NA & NA & 28 \\
\hline Antoniadis \& Richter, 1997 & 1 & 25 & 25 \\
\hline Bartels \& Grotenhuis, 2004 & 1 & 22 & $38^{*}$ \\
\hline Broudy et al., 1978 & 0 & 7 & 10 \\
\hline Caputo \& Watson, 2000 & 0 & 19 & 20 \\
\hline $\begin{array}{l}\text { Dagregorio \& Saint-Cast, } \\
\quad 2004\end{array}$ & 1 & NA & 9 \\
\hline Filippi et al., 2001 & 0 & 22 & 22 \\
\hline Gabel \& Amadio, 1990 & 2 & 30 & 30 \\
\hline Goldfarb et al., 2009 & 0 & 5 & 5 \\
\hline Holmberg, 1991 & 0 & 14 & 14 \\
\hline Kokkalis et al., 2010 & 0 & 17 & 17 \\
\hline Papatheodorou et al., 2015 & 0 & 12 & 12 \\
\hline Rogers et al., 1991 & 0 & 14 & 14 \\
\hline Sarris et al., 2002 & NA & NA & 20 \\
\hline Soltani et al., 2014 & 0 & 4 & 6 \\
\hline Vogel et al., 2004 & 0 & 18 & 18 \\
\hline Total & $5(2.4 \%)$ & 209 & 288 \\
\hline
\end{tabular}

$\mathrm{NA}=$ information not available.

* Two patients were lost to follow-up.

\section{Statistical Analysis}

Given the obvious differences across the included studies, a random-effects model was used to pool the proportions found in the included studies. To measure the degree of inconsistency across the results of the studies, the I2 statistic was calculated. The I2 of $<25 \%, 50 \%$, and $75 \%$ represent low, moderate, and high heterogeneity, respectively. ${ }^{11}$ Increasing values of I2 are associated with greater heterogeneity. When possible and appropriate, results of individual studies were combined to produce a meta-analysis. A pooled proportion of patients with $95 \%$ confidence intervals of proportion was calculated. Results are presented as mean values or $95 \%$ confidence intervals. A p value $\leq 0.05$ was considered statistically significant. Forest and funnel plots for each calculation were created for optimal visualization of the results. No additional analyses (for example, subgroup analyses) were done. Statistical analyses were performed using MedCalc for Windows (MedCalc Software) and IBM SPSS Statistics for Windows version 22 (IBM Corp.).

\section{Results}

Two hundred seventy-eight published studies were retrieved. After removing 64 duplicates, 214 abstracts were screened for content, and 16 papers were included in the final analysis. The search for additional studies by screening the reference lists did not produce any additional re- sults. The study identification flow diagram with reasons for exclusion is shown in Fig. 1.

Fifteen included studies had level IV evidence $e^{2,3,5-10,}$ 12,13,17-21 and one had level III evidence ${ }^{1}$ (Table 2). Methodological quality varied among the studies with 1 study scored as high quality, 14 studies as moderate quality, and 1 as low quality. Fifty-six percent (9) of the studies did not mention if they were funded. Only 19\% (3) of the studies were funded and $25 \%$ (4) were not.

The total number of patients in the included studies was 290 . Mean age was 47 years (1 study provided no information about patient age). Some patients underwent surgery on both sides, resulting in a total of 293 involved elbows. Recurrent symptoms were present in 77 patients (26.6\%), persistent symptoms in 132 patients (45.5\%), and information about recurrence or persistence of symptoms was not available in 81 patients (27.9\%). The dominant side was involved in $61 \%$ of patients (71 of 117) for whom we had data. The mean time until reoperation was only mentioned in 10 studies and consisted of 25 months. The mean followup duration for the 16 studies was 2.3 years. More study characteristics are summarized in Table 3 . Table 4 lists the primary operation and reoperation types per study. The most common primary procedure was in situ decompression, and the most common reoperation was anterior submuscular transposition.

\section{Meta-Analysis}

Pooled results of the 16 studies showed that $85 \%$ of the patients (95\% CI 76\%-92\%) had relief of symptoms after reoperation. The I2 was 74\% (95\% CI 57\%-84\%; Fig. 2). Because the I2 disclosed high heterogeneity, a randomeffects model was used for further analyses.

Thirteen studies $2,3,5,6,8-10,12,13,17,18,20,21$ described changes in pain level. At the final follow-up of 211 elbows, 85\% of the patients (95\% CI 75\%-93\%) had a decrease in pain (Fig. 3). The I2 was 70\% (95\% CI 48\%-83\%). Five (2.4\%) of 209 patients had worsening of preoperatively present pain following reoperation (Table 5).

Sensory and motor function improvement were described in $11^{3,5-10,13,17,18,21}$ and 13 studies, $, 3,5-10,12,13,17,18,21$ representing a total of 183 and 221 elbows, respectively. Sensory improvement occurred in $77 \%$ (95\% CI 61\%$90 \%$ ) and motor function improvement in $77 \%$ (95\% CI $63 \%-88 \%$ ) of elbows (Figs. 4 and 5). The I2 for sensory improvement was $83 \%$, and for motor improvement it was $81 \%$.

Ten studies , $2,3,6,7,9,12,18,19,21$ reported on patients with complete relief of symptoms after reoperation. Patients were considered asymptomatic when the signs and symptoms were completely resolved. Forty-nine of 215 elbows or $23 \%$ of patients $(95 \%$ CI $16 \%-31 \%)$ were asymptomatic at the final follow-up (Fig. 6). The I2 was $47 \%$ (95\% CI $0 \%-74 \%)$.

See Table 6 for detailed calculations for Figs. 2-6.

\section{Discussion}

In our meta-analysis of the outcomes of reoperation for ulnar nerve compression at the elbow, a significant proportion of patients improved and even $23 \%$ of patients were 
TABLE 6. Exact calculations and tests for heterogeneity corresponding with Figs. 2-6

\begin{tabular}{ccccc}
\hline & Sample Size & Proportion & Weight (\%) \\
Authors \& Year & (no. of cases) & $(\%)$ & $95 \% \mathrm{Cl}$ & Random Effects \\
\hline
\end{tabular}

Fig. 2: pooled results of overall symptomatic improvement in proportions of improved patients

\begin{tabular}{l} 
Aleem et al., 2014 \\
Antoniadis \& Richter, 1997 \\
Bartels \& Grotenhuis, 2004 \\
Broudy et al., 1978 \\
Caputo \& Watson, 2000 \\
Dagregorio \& Saint-Cast, 2004 \\
Filippi et al., 2001 \\
Gabel \& Amadio, 1990 \\
Goldfarb et al., 2009 \\
Holmberg, 1991 \\
Kokkalis et al., 2010 \\
Papatheodorou et al., 2015 \\
Rogers et al., 1991 \\
Sarris et al., 2002 \\
Soltani et al., 2014 \\
Vogel et al., 2004 \\
\hline Total (random effects) \\
\hline
\end{tabular}

Fig. 3: pooled results of pain decrease in proportions of improved patients

\begin{tabular}{|c|c|c|c|c|}
\hline Antoniadis \& Richter, 1997 & 25 & 76 & 54.871 to 90.644 & 8.99 \\
\hline Bartels \& Grotenhuis, 2004 & 22 & 40.909 & 20.709 to 63.645 & 8.74 \\
\hline Broudy et al., 1978 & 7 & 85.714 & 42.128 to 99.639 & 6.06 \\
\hline Caputo \& Watson, 2000 & 19 & 94.737 & 73.972 to 99.867 & 8.44 \\
\hline Filippi et al., 2001 & 22 & 81.818 & 59.715 to 94.813 & 8.74 \\
\hline Gabel \& Amadio, 1990 & 30 & 86.667 & 69.278 to 96.245 & 9.31 \\
\hline Goldfarb et al., 2009 & 5 & 80 & 28.358 to 99.495 & 5.24 \\
\hline Holmberg, 1991 & 16 & 75 & 47.623 to 92.734 & 8.07 \\
\hline Kokkalis et al., 2010 & 17 & 100 & 80.494 to 100.000 & 8.2 \\
\hline Papatheodorou et al., 2015 & 12 & 100 & 73.535 to 100.000 & 7.4 \\
\hline Rogers et al., 1991 & 14 & 100 & 76.836 to 100.000 & 6.7 \\
\hline Soltani et al., 2014 & 4 & 75 & 19.412 to 99.369 & 2.23 \\
\hline Vogel et al., 2004 & 18 & 94.444 & 72.706 to 99.859 & 8.48 \\
\hline Total (random effects) & 211 & 84.758 & 74.845 to 92.534 & 100 \\
\hline \multicolumn{5}{|c|}{ ig. 4: pooled results of sensory improvement in proportions of improved patients } \\
\hline Bartels \& Grotenhuis, 2004 & 34 & 26.471 & 12.882 to 44.362 & 10.23 \\
\hline Broudy et al., 1978 & 10 & 80 & 44.390 to 97.479 & 8.52 \\
\hline Caputo \& Watson, 2000 & 19 & 68.421 & 43.450 to 87.424 & 9.57 \\
\hline Dagregorio \& Saint-Cast, 2004 & 9 & 88.889 & 51.750 to 99.719 & 8.31 \\
\hline Filippi et al., 2001 & 22 & 68.182 & 45.128 to 86.135 & 9.76 \\
\hline Gabel \& Amadio, 1990 & 26 & 65.385 & 44.333 to 82.786 & 9.95 \\
\hline Goldfarb et al., 2009 & 5 & 100 & 47.818 to 100.000 & 7.08 \\
\hline Kokkalis et al., 2010 & 17 & 100 & 80.494 to 100.000 & 9.41 \\
\hline Papatheodorou et al., 2015 & 12 & 100 & 73.535 to 100.000 & 8.85 \\
\hline Rogers et al., 1991 & 14 & 78.571 & 49.202 to 95.342 & 9.11 \\
\hline Vogel et al., 2004 & 15 & 66.667 & 38.380 to 88.176 & 9.22 \\
\hline Total (random effects) & 183 & 76.849 & 60.793 to 89.662 & 100 \\
\hline
\end{tabular}




\section{» CONTINUED FROM PAGE 696}

TABLE 6. Exact calculations and tests for heterogeneity corresponding with Figs. 2-6

\begin{tabular}{|c|c|c|c|c|}
\hline Authors \& Year & $\begin{array}{l}\text { Sample Size } \\
\text { (no. of cases) }\end{array}$ & $\begin{array}{c}\text { Proportion } \\
(\%)\end{array}$ & $95 \% \mathrm{Cl}$ & $\begin{array}{c}\text { Weight (\%) } \\
\text { Random Effects }\end{array}$ \\
\hline \multicolumn{5}{|c|}{$\begin{array}{l}\text { Fig. 5: pooled results of improvement in motor function in proportions of improved } \\
\text { patients }\end{array}$} \\
\hline Antoniadis \& Richter, 1997 & 25 & 52 & 31.306 to 72.203 & 8.45 \\
\hline Bartels \& Grotenhuis, 2004 & 38 & 31.579 & 17.503 to 48.653 & 8.85 \\
\hline Broudy et al., 1978 & 9 & 88.889 & 51.750 to 99.719 & 6.92 \\
\hline Caputo \& Watson, 2000 & 14 & 85.714 & 57.187 to 98.221 & 7.67 \\
\hline Dagregorio \& Saint-Cast, 2004 & 9 & 88.889 & 51.750 to 99.719 & 6.92 \\
\hline Filippi et al., 2001 & 22 & 68.182 & 45.128 to 86.135 & 8.3 \\
\hline Gabel \& Amadio, 1990 & 26 & 57.692 & 36.918 to 76.648 & 8.49 \\
\hline Goldfarb et al., 2009 & 5 & 100 & 47.818 to 100.000 & 5.79 \\
\hline Holmberg, 1991 & 15 & 73.333 & 44.900 to 92.213 & 7.78 \\
\hline Kokkalis et al., 2010 & 17 & 100 & 80.494 to 100.000 & 7.96 \\
\hline Papatheodorou et al., 2015 & 12 & 100 & 73.535 to 100.000 & 7.42 \\
\hline Rogers et al., 1991 & 14 & 78.571 & 49.202 to 95.342 & 7.67 \\
\hline Vogel et al., 2004 & 15 & 80 & 51.911 to 95.669 & 7.78 \\
\hline Total (random effects) & 221 & 77.046 & 63.359 to 88.299 & 100 \\
\hline \multicolumn{5}{|c|}{$\begin{array}{l}\text { Fig. 6: pooled results of complete recovery of signs and symptoms in proportions } \\
\text { of improved patients }\end{array}$} \\
\hline Aleem et al., 2014 & 28 & 14.286 & 4.034 to 32.665 & 11.74 \\
\hline Antoniadis \& Richter, 1997 & 25 & 40 & 21.125 to 61.335 & 11.14 \\
\hline Bartels \& Grotenhuis, 2004 & 38 & 21.053 & 9.554 to 37.319 & 13.32 \\
\hline Caputo \& Watson, 2000 & 20 & 15 & 3.207 to 37.893 & 9.97 \\
\hline Dagregorio \& Saint-Cast, 2004 & 9 & 44.444 & 13.700 to 78.799 & 6.23 \\
\hline Gabel \& Amadio, 1990 & 30 & 23.333 & 9.934 to 42.284 & 12.1 \\
\hline Holmberg, 1991 & 16 & 25 & 7.266 to 52.377 & 8.83 \\
\hline Rogers et al., 1991 & 14 & 0 & 0.000 to 23.164 & 8.18 \\
\hline Sarris et al., 2002 & 20 & 20 & 5.733 to 43.661 & 9.97 \\
\hline Vogel et al., 2004 & 15 & 33.333 & 11.824 to 61.620 & 8.52 \\
\hline Total (random effects) & 215 & 22.841 & 15.661 to 30.926 & 100 \\
\hline
\end{tabular}

* Two patients lost to follow-up.

$\dagger$ Postoperative data absent for 3 patients.

completely symptom-free at the final follow-up. A minority of patients had a worsening of pain following reoperation in comparison with preoperative levels.

It should be emphasized that the results describe the proportions of patients who showed improvement but not how much they improved. This was attributable to the variety of outcome measures used in the included studies (for example, Levine-Katz questionnaire, ${ }^{1}$ Patient-Rated Elbow Evaluation, ${ }^{1}$ McGowan grade,${ }^{18}$ modified Novak, Mackinnon and Stuebe questionnaire, ${ }^{3}$ Wilson and Krout classification, ${ }^{7,19}$ Gabel and Amadio scale, ${ }^{6,9}$ neurological examination, ${ }^{8}$ visual analog scale, ${ }^{13,17,20}$ and so forth), which made it impossible to compare the effect size of improvement in any symptoms caused by ulnar nerve entrapment with the findings of other studies. Particularly disappointing was the fact that in most of the reviewed studies, details on the instruments and respective cutoff points used in the studies were not even mentioned. This may be considered as a fundamental source of heterogeneity.

Our study has some caveats. The level of evidence of the studies was low given the observational character of the included studies. It is well known that observational studies overestimate the effect size in comparison to randomized controlled trials. Because of the retrospective design of the included studies, we had to deal with biases like recall bias, selection bias, and so forth. Except for one, ${ }^{1}$ no studies included a comparison group for the revision surgery group. There was also a lack of standardized outcome measurements to facilitate comparisons between studies. The studies also differed from each other in the number of operations performed prior to reoperation.

Altogether, we were not surprised by the finding of high heterogeneity. Given this limitation, any statement about patient selection cannot be made, nor can the optimal surgical solution be identified. 
A

Bartels and Grotenhuis, 2004

Broudy et al., 1978

Caputo et al., 2000

Dagregorio and Saint-Cast, 2004

Filippi et al., 2001

Gabel and Amadio, 1990

Goldfarb et al., 2009

Kokkalis et al., 2010

Papatheodorou et al., 2015

Rogers et al., 1991

Vogel et al., 2004

Total (random effects)

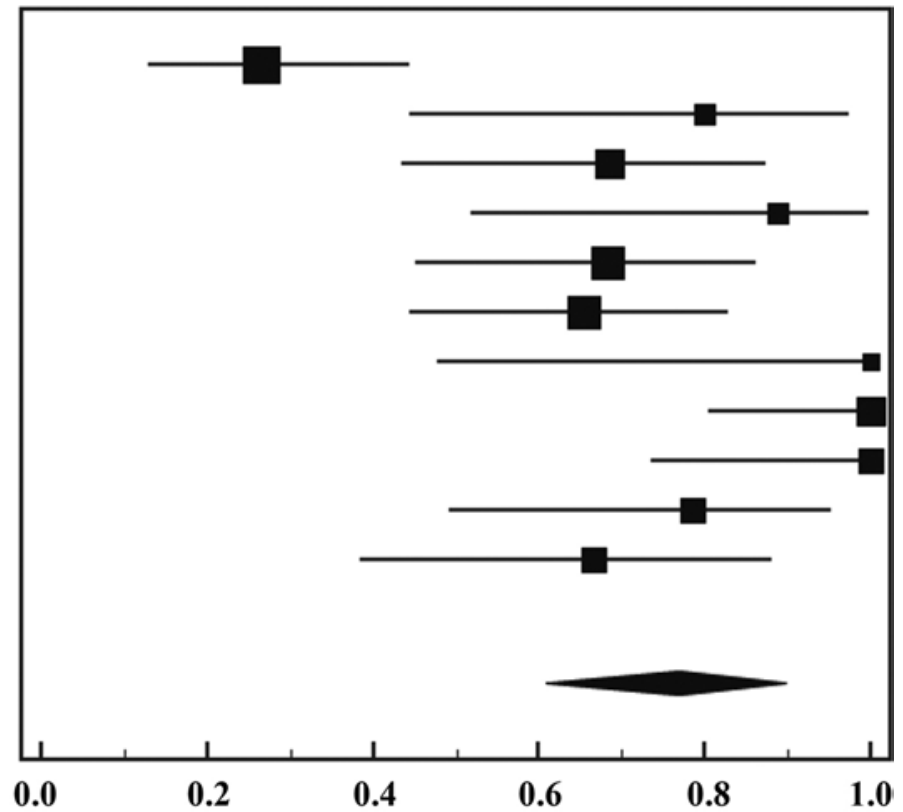

Proportion

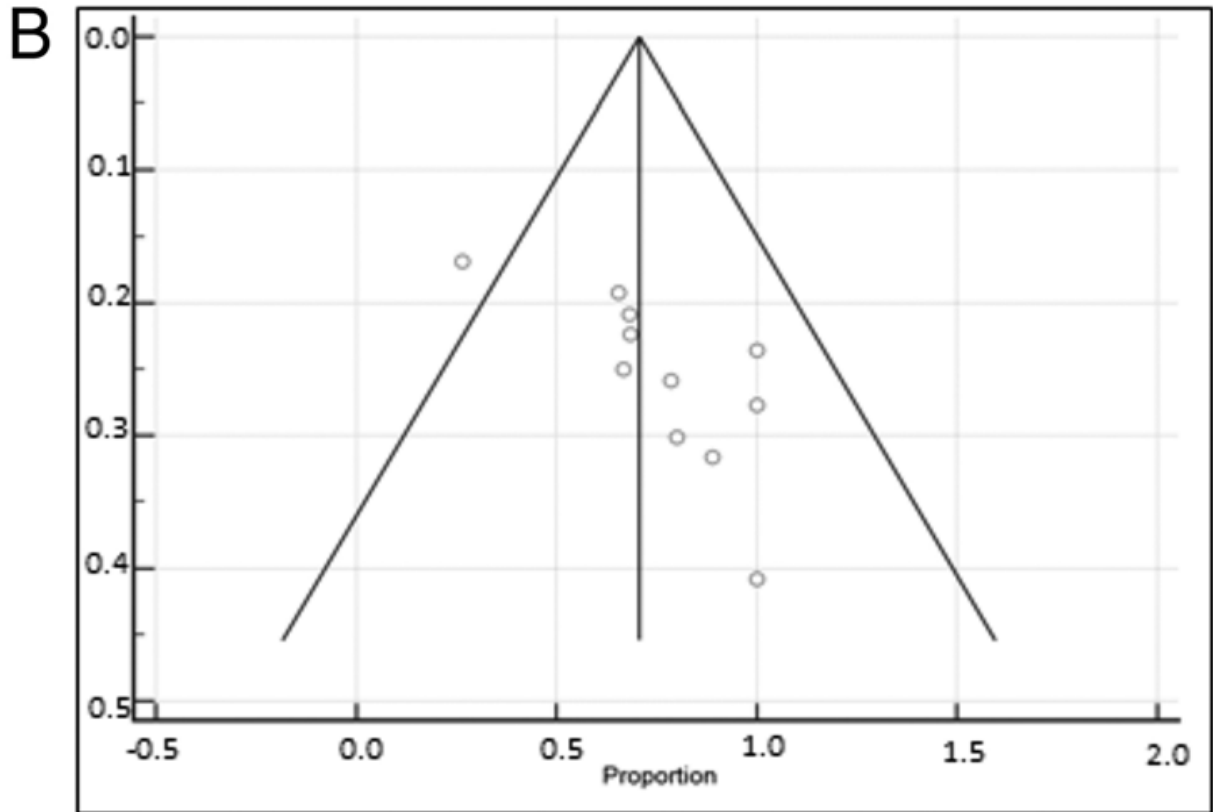

$\mathrm{C}$ Test for heterogeneity

\begin{tabular}{|l|l|}
\hline $\mathrm{Q}$ & 58.7202 \\
\hline $\mathrm{DF}$ & 10 \\
\hline Significance level & $\mathrm{P}<0.0001$ \\
\hline $\mathrm{I}^{2}$ (inconsistency) & $82.97 \%$ \\
\hline $95 \% \mathrm{CI}$ for $\mathrm{I}^{2}$ & 70.91 to 90.03 \\
\hline
\end{tabular}

FIG. 4. Forest plot (A) and funnel plot (B) showing pooled results of sensory improvement in proportions of improved patients with 95\% Cls per included study and table (C) indicating heterogeneity data. 
A

Antoniadis and Richter, 1997

Bartels and Grotenhuis, 2004

Broudy et al., 1978

Caputo and Watson, 2000

Dagregorio and Saint-Cast, 2004

Filippi et al., 2001

Gabel and Amadio, 1990

Goldfarb et al., 2009

Holmberg, 1991

Kokkalis et al., 2010

Papatheodorou et al., 2015

Rogers et al., 1991

Vogel et al., 2004
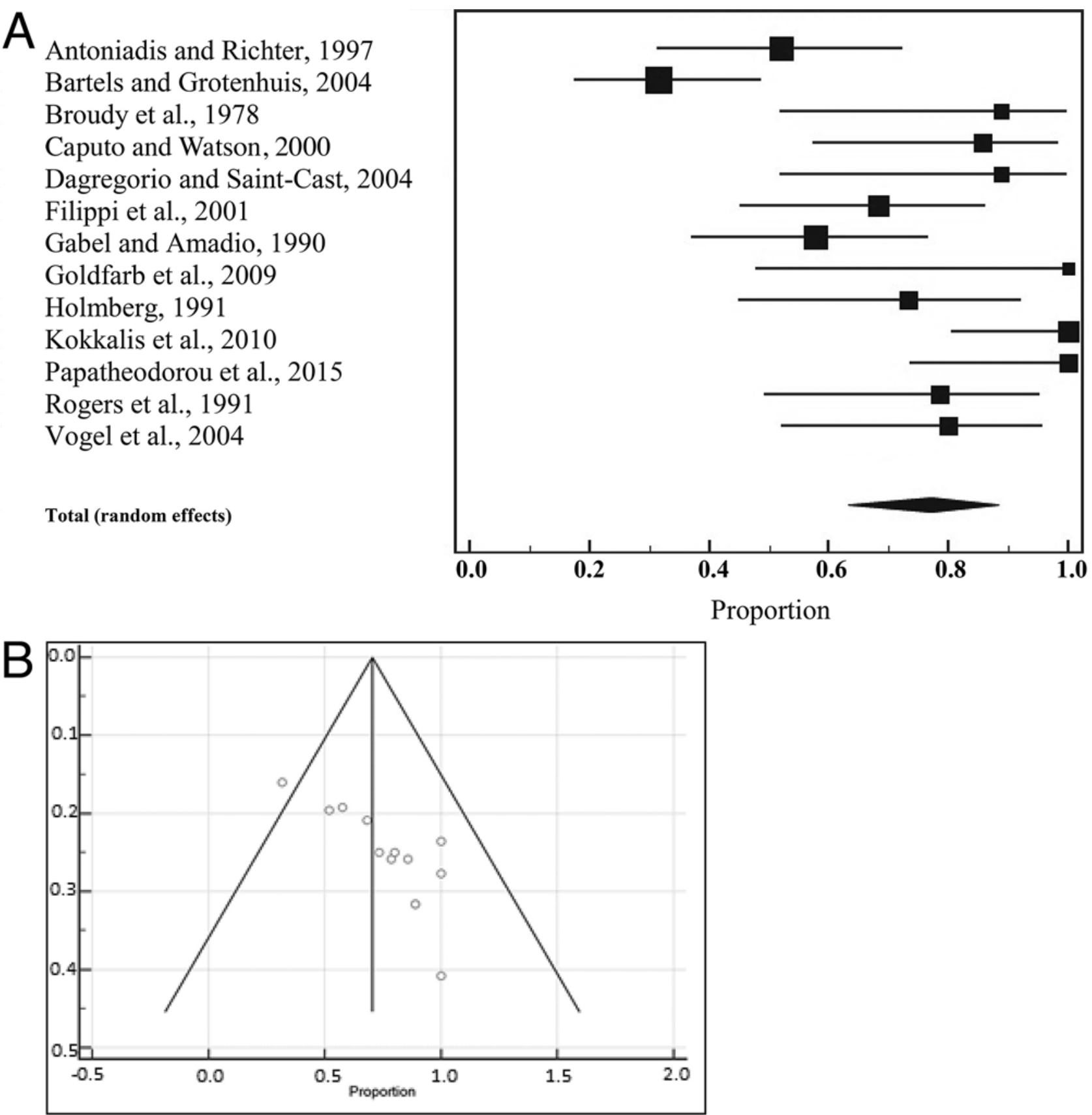

$\mathrm{C}$

\begin{tabular}{|l|l|}
\hline \multicolumn{2}{|l|}{ Test for heterogeneity } \\
\hline $\mathrm{Q}$ & 63.0627 \\
\hline $\mathrm{DF}$ & 12 \\
\hline Significance level & $\mathrm{P}<0.0001$ \\
\hline $\mathrm{I}^{2}$ (inconsistency) & $80.97 \%$ \\
\hline $95 \% \mathrm{CI}$ for $\mathrm{I}^{2}$ & 68.46 to 88.52 \\
\hline
\end{tabular}

FIG. 5. Forest plot (A) and funnel plot (B) showing pooled results of improvement in motor function in proportions of improved patients with $95 \%$ Cls per included study and table (C) indicating heterogeneity data. 
A

Aleem et al., 2014

Antoniadis and Richter, 1997

Bartels and Grotenhuis, 2004

Caputo and Watson, 2000

Dagregorio and Saint-Cast, 2004

Gabel and Amadio, 1990

Holmberg, 1991

Rogers et al., 1991

Sarris et al., 2002

Vogel et al., 2004

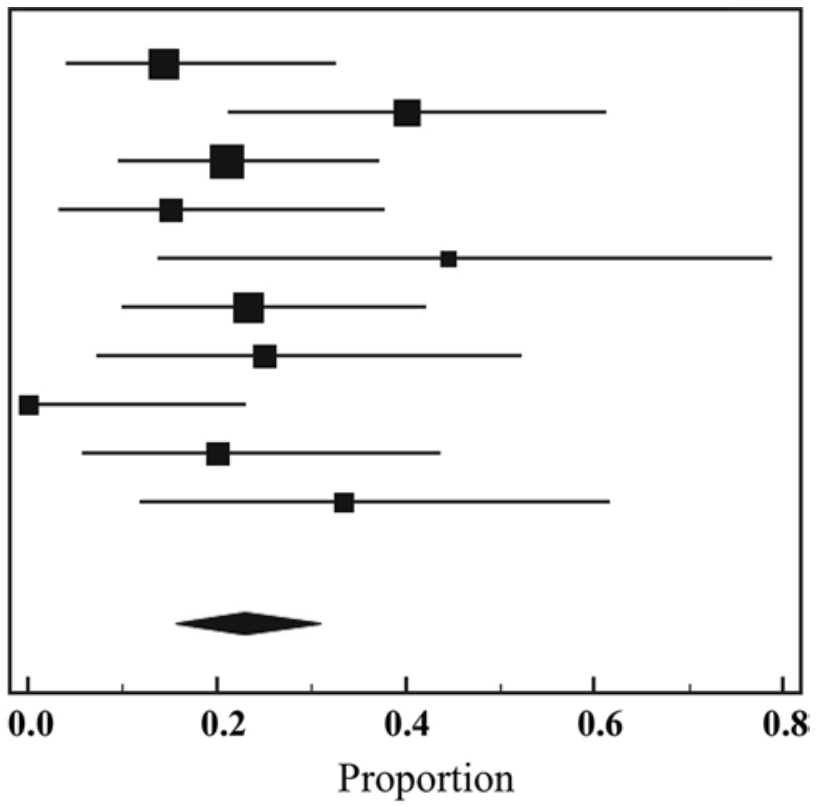

B

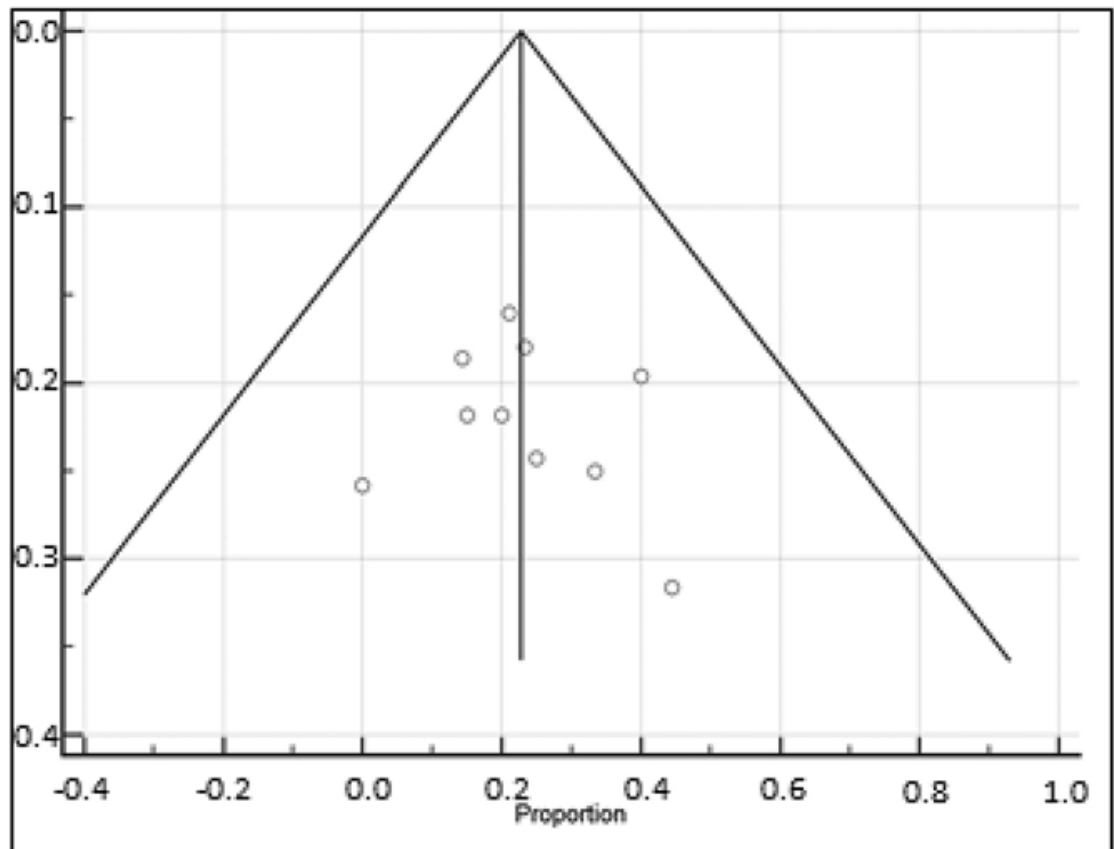

C

\begin{tabular}{|l|l|}
\hline Test for heterogeneity & \\
\hline $\mathrm{Q}$ & 16.9085 \\
\hline DF & 9 \\
\hline Significance level & $\mathrm{P}=0.0502$ \\
\hline $\mathrm{I}^{2}$ (inconsistency) & $46.77 \%$ \\
\hline $95 \%$ CI for $\mathrm{I}^{2}$ & 0.00 to 74.36 \\
\hline
\end{tabular}

FIG. 6. Forest plot (A) and funnel plot (B) showing pooled results of complete recovery of signs and symptoms in proportions of improved patients with $95 \%$ Cls per included study and table $(C)$ indicating heterogeneity data. 


\section{Conclusions}

Despite the limitations of this study, it is most likely that the majority of patients will benefit to a greater or lesser extent from surgical reexploration of the ulnar nerve after previously failed surgical treatment. However, surgeons performing a reexploration must be competent, capable, and comfortable with the procedure.

In our opinion, further research should focus on a well-designed, adequately powered prospective randomized controlled trial with long-term follow-up ( $>2$ years). Moreover, considering the number of patients with the recurrence of persistent symptoms of ulnar nerve compression, a multicenter approach is recommended. This should also include a combination of quantitative clinical findings for pain, motor function, sensation, and patient-related outcomes with satisfaction rates required for adequate evaluation of surgical procedures.

\section{Acknowledgments}

We thank H. W. J. Deurenberg-Vos for the database search and A. F. J. de Haan for statistical assistance.

\section{References}

1. Aleem AW, Krogue JD, Calfee RP: Outcomes of revision surgery for cubital tunnel syndrome. J Hand Surg Am 39:2141-2149, 2014

2. Antoniadis G, Richter HP: Pain after surgery for ulnar neuropathy at the elbow: a continuing challenge. Neurosurgery 41:585-591, 1997

3. Bartels RHMA, Grotenhuis JA: Anterior submuscular transposition of the ulnar nerve. For post-operative focal neuropathy at the elbow. J Bone Joint Surg Br 86:998-1001, 2004

4. Bartels RHMA, Menovsky T, Van Overbeeke JJ, Verhagen WIM: Surgical management of ulnar nerve compression at the elbow: an analysis of the literature. J Neurosurg 89:722727, 1998

5. Broudy AS, Leffert RD, Smith RJ: Technical problems with ulnar nerve transposition at the elbow: findings and results of reoperation. J Hand Surg Am 3:85-89, 1978

6. Caputo AE, Watson HK: Subcutaneous anterior transposition of the ulnar nerve for failed decompression of cubital tunnel syndrome. J Hand Surg Am 25:544-551, 2000

7. Dagregorio G, Saint-Cast Y: Simple neurolysis for failed anterior submuscular transposition of the ulnar nerve at the elbow. Int Orthop 28:342-346, 2004

8. Filippi R, Charalampaki P, Reisch R, Koch D, Grunert P: Recurrent cubital tunnel syndrome. Etiology and treatment. Minim Invasive Neurosurg 44:197-201, 2001

9. Gabel GT, Amadio PC: Reoperation for failed decompression of the ulnar nerve in the region of the elbow. J Bone Joint Surg Am 72:213-219, 1990

10. Goldfarb CA, Sutter MM, Martens EJ, Manske PR: Incidence of re-operation and subjective outcome following in situ decompression of the ulnar nerve at the cubital tunnel. J Hand Surg Eur Vol 34:379-383, 2009

11. Higgins JPT, Thompson SG, Deeks JJ, Altman DG: Measuring inconsistency in meta-analyses. BMJ 327:557-560, 2003

12. Holmberg J: Reoperation in high ulnar neuropathy. Scand J Plast Reconstr Surg Hand Surg 25:173-176, 1991

13. Kokkalis ZT, Jain S, Sotereanos DG: Vein wrapping at cubi- tal tunnel for ulnar nerve problems. J Shoulder Elbow Surg 19 (2 Suppl):91-97, 2010

14. Moga C, Guo B, Schopflocher D, Harstall C: Development of a quality appraisal tool for case series studies using a modified Delphi technique. Edmonton: Institute of Health Economics, 2012 (https://www.ihe.ca/publications/developmentof-a-quality-appraisal-tool-for-case-series-studies-using-amodified-delphi-technique) [Accessed January 23, 2018]

15. Moher D, Liberati A, Tetzlaff J, Altman DG: Preferred reporting items for systematic reviews and meta-analyses: the PRISMA statement. BMJ 339:b2535, 2009

16. Mondelli M, Giannini F, Ballerini M, Ginanneschi F, Martorelli E: Incidence of ulnar neuropathy at the elbow in the province of Siena (Italy). J Neurol Sci 234:5-10, 2005

17. Papatheodorou LK, Williams BG, Sotereanos DG: Preliminary results of recurrent cubital tunnel syndrome treated with neurolysis and porcine extracellular matrix nerve wrap. J Hand Surg Am 40:987-992, 2015

18. Rogers MR, Bergfield TG, Aulicino PL: The failed ulnar nerve transposition. Etiology and treatment. Clin Orthop Relat Res (269):193-200, 1991

19. Sarris I, Göbel F, Gainer M, Vardakas DG, Vogt MT, Sotereanos DG: Medial brachial and antebrachial cutaneous nerve injuries: effect on outcome in revision cubital tunnel surgery. J Reconstr Microsurg 18:665-670, 2002

20. Soltani AM, Allan BJ, Best MJ, Mir HS, Panthaki ZJ: Revision decompression and collagen nerve wrap for recurrent and persistent compression neuropathies of the upper extremity. Ann Plast Surg 72:572-578, 2014

21. Vogel RB, Nossaman BC, Rayan GM: Revision anterior submuscular transposition of the ulnar nerve for failed subcutaneous transposition. Br J Plast Surg 57:311-316, 2004

22. von Elm E, Altman DG, Egger M, Pocock SJ, Gøtzsche PC, Vandenbroucke JP: The Strengthening the Reporting of Observational Studies in Epidemiology (STROBE) Statement: guidelines for reporting observational studies. Int J Surg 12:1495-1499, 2014

23. Wells GA, Shea B, O'Connell D, Peterson J, Welch V, Losos M, et al: The Newcastle-Ottawa Scale (NOS) for assessing the quality of nonrandomised studies in meta-analyses. Ottawa Hospital Research Institute. (http://www.ohri.ca/ programs/clinical_epidemiology/oxford.asp) [Accessed January 23,2018$]$

\section{Disclosures}

The authors report no conflict of interest concerning the materials or methods used in this study or the findings specified in this paper.

\section{Author Contributions}

Conception and design: all authors. Acquisition of data: Natroshvili, Walbeehm. Analysis and interpretation of data: all authors. Drafting the article: all authors. Critically revising the article: all authors. Reviewed submitted version of manuscript: all authors. Approved the final version of the manuscript on behalf of all authors: Natroshvili. Statistical analysis: Natroshvili, Walbeehm, Bartels. Administrative/technical/material support: van Alfen, Bartels. Study supervision: Walbeehm, van Alfen, Bartels.

\section{Correspondence}

Tinatin Natroshvili: Radboud University Medical Center, Nijmegen, The Netherlands. tina_natroshvili@hotmail.com. 